\title{
Significant depositional changes offshore the Nile Delta in late third millennium BCE: relevance for Egyptology
}

\author{
Jean-Daniel Stanley and Sarah E. Wedl \\ Mediterranean Basin (MEDIBA) Program, 6814 Shenandoah Court, Adamstown, Maryland 21710, USA \\ Correspondence: Jean-Daniel Stanley (stanleyjd0@gmail.com)
}

Relevant dates: $\quad$ Received: 28 July 2020 - Accepted: 17 December 2020 - Published: 22 February 2021

How to cite:

Stanley, J.-D. and Wedl, S. E.: Significant depositional changes offshore the Nile Delta in late third millennium BCE: relevance for Egyptology, E\&G Quaternary Sci. J., 70, 83-92, https://doi.org/10.5194/egqsj-70-83-2021, 2021.

Abstract:

No environmental factor has been as critically important for Egypt's ancient society through time as sufficiently high annual flood levels of the Nile River, the country's major source of fresh water. However, interpretation of core analysis shows reduced depositional accumulation rates and altered compositional attributes of the sediment facies deposited seaward of the Nile Delta during a relatively brief period in the late third millennium BCE. These changes record the effects of displaced climatic belts, decreased rainfall, lower Nile flows, and modified oceanographic conditions offshore in the Levantine Basin, primarily from 2300 to $2000 \mathrm{BCE}$, taking place at the same time as important geological changes identified by study of cores collected in the Nile Delta. It turns out that integrated multidisciplinary Earth science and archaeological approaches at dated sites serve to further determine when and how such significant changing environmental events had negative effects in both offshore and landward areas.

This study indicates these major climatically induced effects prevailed concurrently offshore and in Nile Delta sites and at about the time Egypt abandoned the Old Kingdom's former political system and also experienced fragmentation of its centralized state. In response, the country's population would have experienced diminished agricultural production leading to altered societal, political, and economic pressures during the late Old Kingdom to First Intermediate Period at ca. 2200 to 2050 BCE.

Kurzfassung: $\quad$ Für die Gesellschaft des Alten Ägypten war im Laufe der Zeit kein anderer Umweltfaktor so entscheidend wie die ausreichend hohen jährlichen Hochwasserstände des Nils, der wichtigsten Süßwasserquelle des Landes. Allerdings deuten Bohrkernanalysen darauf hin, dass während eines relativ kurzen Zeitraums gegen Ende des 3.Jahrtausends v. u. Z. geringere Ablagerungsraten sowie Veränderungen in der Zusammensetzung der Sedimentfazies auftraten, die sich meerwärts des Nildeltas akkumulierten. Diese Veränderungen resultierten aus einer Verschiebung der Klimagürtel, geringeren Niederschlägen und Nilabflüssen sowie veränderten ozeanographischen Bedingungen im Levantinischen Becken um etwa 2300 bis 2000 v. u. Z., einer Zeit weiterer geologischer Veränderungen, deren Effekte sich ebenfalls in den Bohrkernen nachweisen lassen. Wie sich nun zeigt, helfen integrierte multidisziplinäre geowissenschaftliche und archäologische Untersuchungen im Umfeld archäologischer Stätten dabei, näher zu bestimmen, wann und wie sich solche bedeutenden Umweltereignisse negativ auswirkten, sowohl vor der Küste, als auch im Delta selbst. 
Die Ergebnisse dieser Studie legen nahe, dass sich diese großen klimabedingten Effekte gleichzeitig vor der Küste und im Umland archäologischer Stätten im Nildelta nachweisen lassen, ungefähr im gleichen Zeitraum, als in Ägypten das politische System des Alten Reiches zerfiel und die Fragmentierung des zuvor zentralistischen Staates einsetzte. Eine mögliche Konsequenz daraus wäre der Rückgang der landwirtschaftlichen Produktion, was wiederum zu veränderten gesellschaftlichen, politischen und wirtschaftlichen Bedingungen für die Bevölkerung des Landes vom späten Alten Reich bis zur Ersten Zwischenzeit um ca. 2200 bis 2050 v. u. Z. geführt haben könnte.

\section{Introduction}

Climatic conditions evolved considerably during the Middle to Late Holocene as interpreted by study of the sedimentary record examined in Egypt, northeastern Africa, and the Levant (Said, 1993; Gasse, 2000; Bar-Matthews and Ayalon, 2011; Marriner et al., 2013; Kaniewski et al., 2018). The present survey focuses primarily on significantly decreased sediment accumulation rates and marked lithofacies changes seaward of the Nile Delta that became more pronounced after the African Humid Period (AHP), from about 5000 to 4000 years ago (Maldonado and Stanley, 1976; Krom et al., 2002; Stanley et al., 2003; Ducassou et al., 2009; Kholeif and Mudie, 2009; Blanchet et al., 2013; Revel et al., 2015). Stratigraphic, lithological, and compositional attributes of deposits accumulating in lower Egypt and the delta during that period record increased effects of aridity and desertification (Calvert and Fontugne, 2001; Stanley et al., 2003; Ducassou et al., 2009; Kholeif and Mudie, 2009; Kholeif and Ibrahim, 2010; Bernhardt et al., 2012; Blanchet et al., 2013; Marriner et al., 2013; Pennington et al., 2019). Altered monsoonal rainfall patterns and intensities induced erosional changes in Nile highland source terrains south of Egypt, including Ethiopia and the East African lakes region, which modified the hydrography of both the Blue Nile and the White Nile during the Holocene (Gasse, 2000; Blanchet et al., 2015; Woodward et al., 2015). These changes induced substantially lower Nile flows northward to and across the Sudan and Egypt and significantly reduced rates of fresh water and sediment discharged into the delta (Stanley, 2019). Interpreting possible climatic effects seaward of the delta in the Mediterranean during this period is of major consideration in the present study.

The millennium from ca. 5000 to 4000 years BP (before present) comprises Egypt's early dynasties (numbered I to XI). This time span includes the Early Dynastic Period and Old Kingdom to the First Intermediate Period as established archaeologically (Shaw, 2000; Bard, 2008). It was during pharaonic rule of the Old Kingdom that Egypt's civilization was already reaching stunning levels, including major phases of social and municipal expansion, monumental construction projects along the Nile, and impressive artistic development (Shaw, 2000). Toward the latter part of that millennium, however, some notable degradation occurred, such as of pyramids (see Fig. 5 herein for example) during Egypt's late Old Kingdom and First Intermediate Period. These took place at, or about, the time when environmental conditions were evolving extensively, not only in the Nile Delta but also offshore as highlighted in the present review. Whether the country's population could have been affected by such altered climatic conditions at that time will be considered herein.

\section{General background}

Depositional changes observed offshore are recorded between the outer continental shelf and more distal, deeper slope sectors north of the delta in the eastern Mediterranean (Ducassou et al., 2009; Kholeif and Ibrahim, 2010). Studies at sea here (Fig. 1a) in recent years have recorded altered attributes through time in radiocarbon-dated sediment core sections, including markers such as texture, mineralogy and isotopes, and biogenic components. Together, these reveal that after ca. 5000 years BP proportions of eolian sediment, derived from both proximal and more distal arid terrains and deserts, were increasing in both deltaic and offshore deposits. By ca. 4000 years BP observations indicate that desert conditions had fully reached Egypt's Sahara (Calvert and Fontugne, 2001; Krom et al., 2002; Marriner et al., 2013; Blanchet et al., 2013; Pennington et al., 2019). For the purposes here we define three periods: from $\sim 11000$ to $\sim 8000$ years $\mathrm{BP}$ is Early Holocene, from $\sim 8000$ to $\sim 4500$ years BP is Middle Holocene, and from $\sim 4500$ years $\mathrm{BP}$ to present is Late Holocene. The Middle to Late Holocene is a time of prime interest here that has experienced significant shifts in amounts of water and sediment derived from Blue Nile, and to a lesser extent White Nile, upland source areas that were dispersed downslope to lower Egypt, its delta plain, and offshore. For example, Revel et al. (2015) proposed that decreased proportions of clastic sediments from Ethiopia's Blue Nile were at times derived from ca. 6 to $3.1 \mathrm{ka}$. Such changes resulted from altered rainfall patterns in East African highland source areas and increased aridification (Marriner et al., 2013; Revel et al., 2015) that markedly reduced sediment discharged by Nile flows at the coastal margin. This resulted in lower proportions of fluvial terrigenous and volcanically derived material released over more limited deltaic and offshore areas (Stanley and Warne, 1993). 


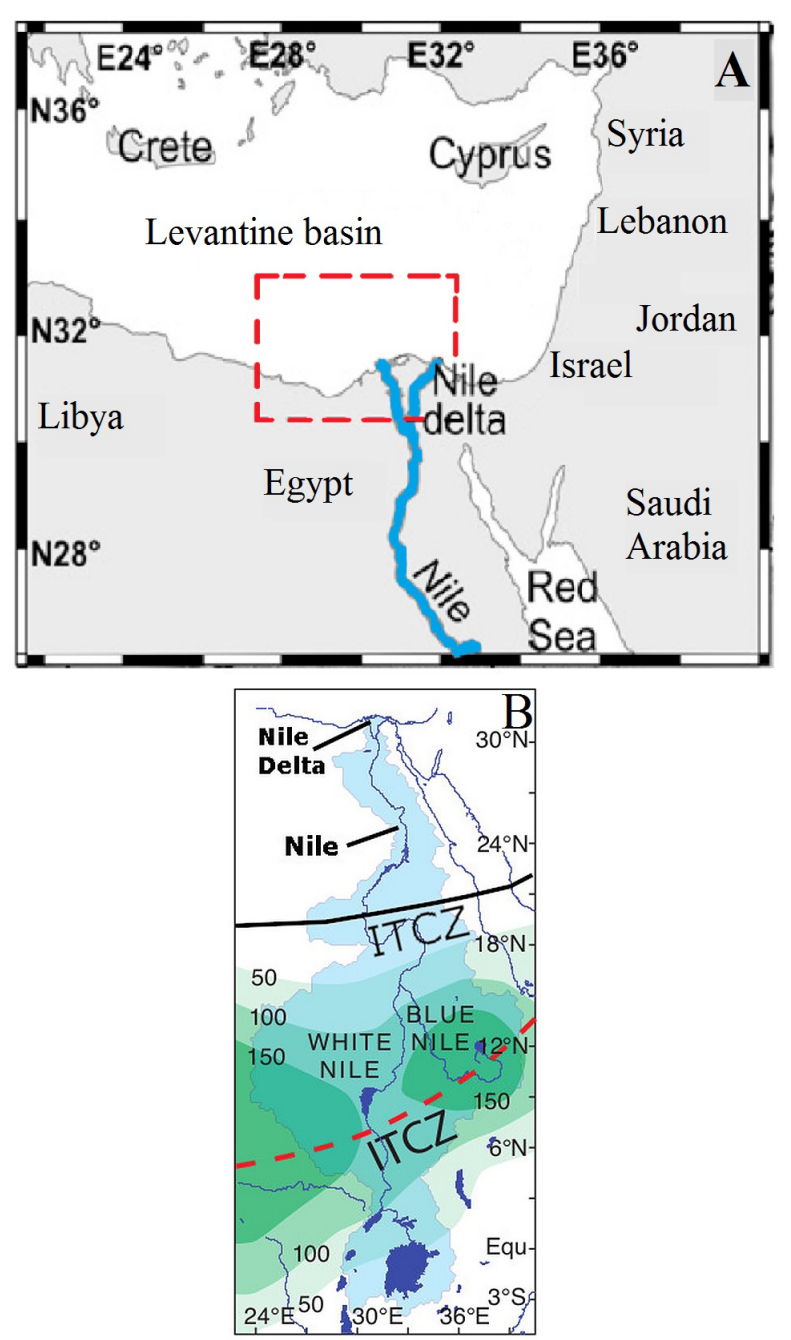

Figure 1. (a) Levantine Basin in the eastern Mediterranean showing the study area NW of Egypt's lower Nile River and delta. (b) Nile catchment basin (in blue) shows two approximate latitudinal positions of the June-July-August Intertropical Convergence Zone (ITCZ): solid black line denotes monsoonal shift to the north during Early to Middle Holocene; dashed red line denotes its Late Holocene move toward present position farther to the south. Numbers 50 to 150 are rainfall values (in $\mathrm{mm}$ ), for the monsoon season (after Marriner et al., 2012, their Fig. 1b, modified here by authors of this article).

Egypt's then modest population along the Nile valley and lower river stretches had initially used a portion of deltaic plain terrains for pasturing and later for cultivation. The latter depended increasingly on channelization and diversion of water for irrigation from the Nile, that country's major source of fresh water (Butzer, 1976, 1984). Critical in this respect is the amount of freshwater discharge reaching the delta that responded largely to regional climate change induced by north-south latitudinal migration of the Intertropical Convergence Zone (ITCZ; Fig. 1b). Nile discharge fluctuations were also induced by more frequent and periodically intense El Niño-Southern Oscillation (ENSO) cycles that, at a centennial scale, affected water flow and sediment delivery to lower Egyptian sectors and its coast (Said, 1993; Krom et al., 2002; Marriner et al., 2012).

The focus here is on altered sediment databases recorded offshore Egypt that can be compared with those of similar age previously examined in the Nile Delta and farther inland. Data from dated sediment cores in the delta's northern sector and coastal area identify a period of markedly decreased depositional rates. This phase prevailed primarily during a 200- to 300-year period, between ca. 4300 and 4000 years BP (Stanley, 2019), and spans that of a climatically altered period generally termed the "ca. 4200 year BP event". This phase has been discussed by climatologists, geographers, sedimentologists, palynologists, and others, who have examined the Holocene record in different sectors of the eastern Mediterranean, Levant, and beyond (Weiss et al., 1993; BarMatthews and Ayalon, 2011; Kaniewski et al., 2018).

Other natural phenomena considered include neotectonic activity, as recorded by stratal deformation and offsets observed in seismic subbottom surveys that could have triggered some downslope displacement of sediment by gravitative flows such as turbidites and slumps during the Holocene. Near-surface displacement may have been set in motion by deep-seated underlying salt tectonics, isostatic readjustment of consolidated strata at depth, or shifts triggered by episodic shallow earthquake motion in the late Quaternary and continuing to the present (Ross and Uchupi, 1977; Kebeasy, 1990; Bellaiche et al., 1999; El-Sayed et al., 2004). Eustatic sea-level rise could also account for some changes in offshore sedimentation, especially during the period when the $>100 \mathrm{~m}$ rise in sea level occurred from the Late Pleistocene (ca. 18000 years BP) to the Middle Holocene (ca. 7500 years BP). This rapid rate of rise then decreased markedly by about 7500 to 6000 years BP to an elevation of -8 to $-6 \mathrm{~m}$ below present sea level and then further declined by ca. 4000 years $\mathrm{BP}$, attaining a level of about -3 to $-2 \mathrm{~m}$ beneath the present level (Fleming et al., 1998; Sivan et al., 2001). The shelf's once subaerially exposed surface was submerged as the shoreline retreated landward toward the south. The delta's coastal margin from ca. 6000 to 4000 years BP (Fig. 2) appears to have reached its northward position on what once had been near the mid-shelf (Stanley and Warne, 1993). It then continued its southward retreat as a function of coastal erosion and concurrent subsidence of the inner shelf to midshelf and low-lying northern delta substrate (Stanley and Clemente, 2017; Stanley, 2019).

\subsection{Early to Middle Holocene Nile offshore sedimentation}

Seafloor deposits of Holocene age seaward of the delta, examined in about 150 gravity and piston sediment cores by specialists in diverse fields, were recovered across extensive offshore areas. These are curated in marine research centers 


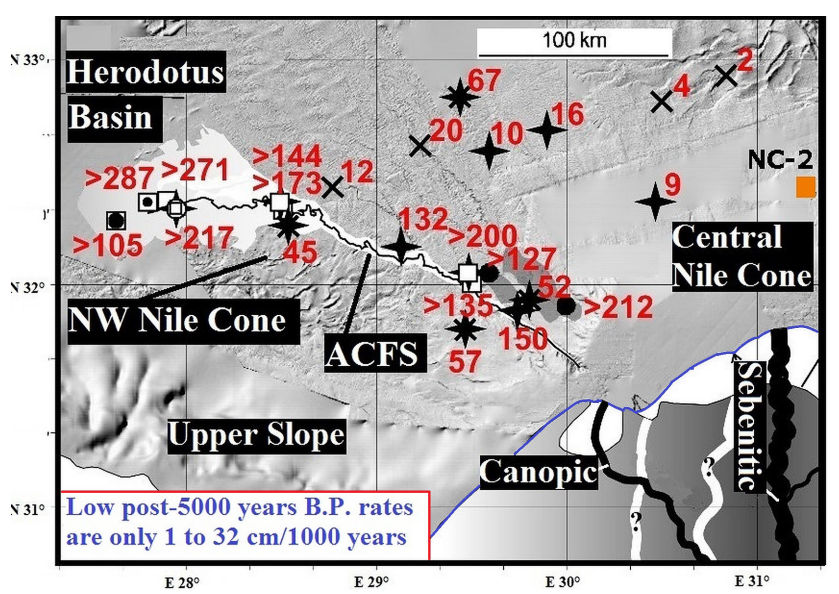

Figure 2. Study area off the NW Nile Delta (in lower right of figure) shows the Herodotus Basin (>3000 m), NW and central sectors of the Nile Cone, Alexandria canyon-fan system (ACFS), corner of delta in northern Egypt, and positions of 23 cores offshore. Numbers in red: sedimentation rates in centimeters per 1000 years for lower core sections dated from ca. 10000 to ca. 5000 years BP (data after Ducassou et al., 2009, their Figs. 13 and 14, modified here by the authors of this article). These record high rates of Nile sediment discharge during wetter climate. Different symbols at each core site identify major sediment types. In marked contrast, upper sections of the same cores, dated from ca. 5000 years BP to Late Holocene, record much lower rates of Nile discharge (only 1 to $32 \mathrm{~cm}$ per 1000 years; also after Ducassou et al., 2009) during the period of increased aridity.

and museum collections, including those in Egypt (Kholeif and Mudie, 2009), Europe (Ducassou et al., 2009), the United States (Maldonado and Stanley, 1976), and elsewhere. Core samples serve to compare dated Early (from 11000 years BP) to dated Late Holocene lithofacies changes between Egypt's Nile continental shelf and deeper sectors. Focus here is on offshore slope deposits that accumulated on the upper surface of a large elongated bulge off Egypt, termed the Nile Cone, which extends seaward of the delta's shelf and upper slope. The study area is primarily on the pronounced cone sector that trends northwest of the delta's shelf edge (> $200 \mathrm{~m}$ depth) to the deep $(>3000 \mathrm{~m}$ ) Herodotus Basin plain (Fig. 2). Seafloor isobaths in this area are shown in Ducassou et al. (2009) and are well defined on larger-scale charts such as the one compiled by the US Defense Mapping Agency Hydrographic Center (1972, N.O. 310) at a scale of $1: 2849300$.

The cone in this sector is $\sim 225 \mathrm{~km}$ long, increases in width downslope to $\sim 250 \mathrm{~km}$ at its base, and covers ca. $50000 \mathrm{~km}^{2}$. An elongate submarine canyon, traced on the surface of the NW cone, meanders downslope (Fig. 2); it extends from off-Nile mouths of the modern Rosetta and former Canopic branches to the lower cone. This Alexandria canyon-fan system (ACFS) actively distributed sediment seaward, primarily prior to ca. 5000 years BP during the
Middle Holocene. Sedimentation patterns distributed on the Nile shelf, between the delta and its upper fan, have been defined by Summerhayes et al. (1978), Sestini (1992), and also Egyptian agencies including the Coastal Research Institute and the National Institute of Oceanography and Fisheries.

Shelf and upper-slope sediments record influences of the Late Holocene to recent wind- and wave-driven bottom current transport, the latter presently most active along the inner shelf and mid-shelf. These processes shift shallow seafloor sediment mainly eastward and, locally, seaward off the shelf (UNESCO/UNDP and Arab Republic of Egypt, 1978; Frihy and Dewidar, 2003; Kholeif and Mudie, 2009). Materials normally originating on the shelf and recovered in upperslope and deeper Nile Cone cores indicate seaward displacement at times of intensified coastal margin circulation that swept the seafloor. Sedimentary structures and the composition of strata show that, once off the shelf, some sediments were shifted farther downslope by gravitative processes such as turbidity currents and mass flows. These mechanisms displaced clay and silt and, to a lesser extent, sand of fluvial Nile and eolian origin, along with shelf material of terrigenous, carbonate, and biogenic origin. Core analyses reveal transport of these components in varying proportions via the ACFS and NW cone's surface to more distal sectors primarily during the Early to Middle Holocene (Stanley and Maldonado, 1977; Ducassou et al., 2009; Kholeif and Ibrahim, 2010). It is also likely that some of the finer sediment components and low accumulation rates may indicate displacement from the NW-oriented cone eastward toward the central Nile Cone as well.

Sediments displaced from land to considerable distances offshore during that period were derived primarily from Nile flood discharge, which is strong in summer, across the delta's coastal margin and then seaward. These largely land-derived materials could be further shifted downslope and dispersed as they settled across climatically controlled, well-stratified intermediate and bottom water masses. One of these sediments distributed well offshore is sapropel, a depositional sequence typically comprising a dark gray to black, mostly silt and clay, organic-rich sediment unit of variable thickness (log in Fig. 3).

This dark unit accumulated beneath oxygen-deficient bottom water and reached euxinic seafloor conditions. High amorphic organic carbon content (58\%-72\%) indicates good preservation of autochthonous planktonic organic matter (Kholeif and Ibrahim, 2010). Stagnation in deep water, increases in primary productivity, and other associated oceanographic conditions are discussed by Rohling and Hilgen (1991) and Krom et al. (2002). Gray deposits, below and above the dark unit, were deposited on the seafloor in less well stratified water and only partially reduced oxygenated conditions.

The youngest sapropel sequence, termed S1, is dated to the AHP, from the Early to Middle Holocene (ca. 9500 to 6000 years BP). The climate during its deposition, one of ex- 


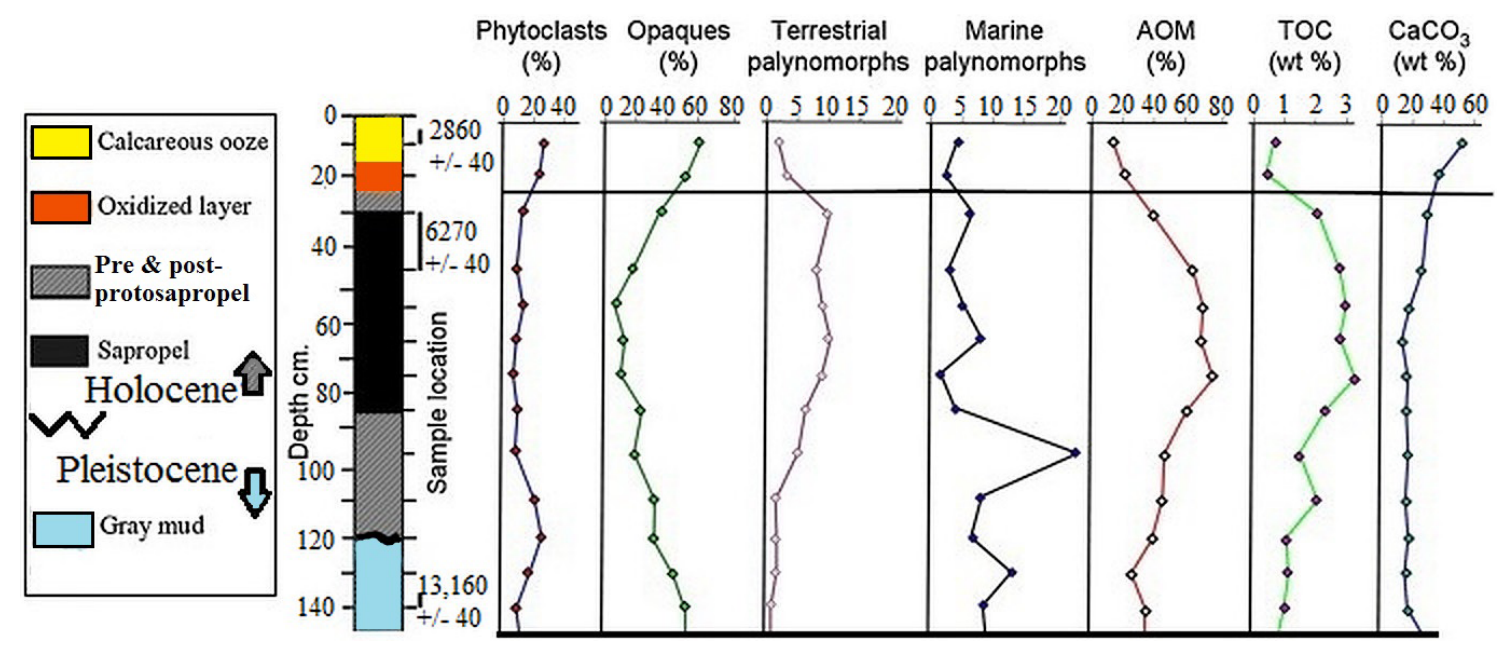

Figure 3. Stratigraphic log of core NC-2 (location shown in Fig. 2) records an Early to Middle Holocene sapropel S1 sequence formed during a period of ca. 3500 years and a much thinner Middle to Late Holocene upper core section of oxidized layer and calcareous ooze. Note proportions of compositional components that change markedly at about $25 \mathrm{~cm}$ from core top, at ca. late 4000 years BP (after Kholeif and Ibrahim, 2010). AOM is amorphous organic matter, and TOC is total organic carbon.

tensive to moderate rainfall, was in large part a response to northward displacement of the ITCZ (Fig. 1b; Said, 1993; Krom et al., 2002; Marriner et al., 2013). The $\mathrm{S} 1$ sequence is recovered at water depths usually greater than 500 to $600 \mathrm{~m}$ on the cone (Maldonado and Stanley, 1976; Ducassou et al., 2009). Complete $S 1$ sequences can range from $\sim 50$ to $>200 \mathrm{~cm}$ in thickness. The gray deposits underlying and covering the dark gray to black unit usually include finely laminated silty clay and clayey silt mixes; their sedimentary structures indicate some were emplaced by bottom currents and others by fine-grained turbidity currents. The age and composition of these deposits indicate they were released beyond the delta's shelf during the AHP when East African source lake levels, Nile floods, and amounts of sediment discharge were at or near the optimum (Fig. 4a, b) and maximum aridity did not yet prevail (Gasse, 2000; Kholeif and Mudie, 2009; Revel et al., 2015; Pennington et al., 2017). Compositional analyses of both deltaic and offshore core facies indicate that the upper Blue Nile volcanic province in Ethiopia (Fig. 4c) was the major source of sediment released to and beyond the delta during that period.

\subsection{Reduced depositional rates after 5000 years BP}

Uppermost sedimentary sequences recovered in cores seaward of the delta and discussed here have received much less attention than the underlying sapropel sequences discussed in the previous section. Their lithofacies and compositional attributes differ significantly from the older S1 sequence. Notably, most sections are much thinner, generally only $\sim 20$ to $30 \mathrm{~cm}$ or less (Stanley and Maldonado, 1977). From the base upward, these present partially laminated silty clay and clayey silt layers that, in some cores, change upward and dis- play a mottled tan, brown, or orange coloration, which is indicative of increasingly oxygenated water conditions above the $\mathrm{S} 1$ sequence (Fig. 3). These younger sections commonly evolve upward to a bioturbated silt and clay ooze, rich in calcareous carbonate content (up to $50 \%$ ), and grain size that can become coarser toward the core top. Although recovered at considerable water depth, some upper deposits include shallow seafloor components derived from the shelf; these became incorporated with deeper-water materials during downslope transport. Such strata may present sedimentary structures indicative of displacement by bottom currents or by relatively low density sand and silt to fine-grained turbidite flows. Uppermost sediments were released above older S1 sequences not only within the ACFS but also on adjacent cone surfaces (Fig. 2). Their lithologic attributes, much different from those of underlying S1 sequences, resulted from southern displacement of the ITCZ (Fig. 1b) and also from some effects of ENSO cycles during and after the Middle Holocene (Marriner et al., 2013; Pennington et al., 2017).

Average sediment accumulation rates in 23 cores recovered along the SE to NW trending Nile Cone were calculated for two age groups in each core based on sediment thickness and radiocarbon dates using planktonic foraminifera (Ducassou et al., 2009; Kholeif and Mudie, 2009; Kholeif and Ibrahim, 2010; Blanchet et al., 2013). An older group comprises lower core sections dated from ca. 10000 to ca. 5000 years BP and usually includes the S1 sequence. Depositional rates for this Early to Middle Holocene period range from $>287$ to $2 \mathrm{~cm}$ per 1000 years (Fig. 2). The average overall rate for all Early to Middle Holocene values in the 23 cores is $\sim 106 \mathrm{~cm}$ per 1000 years. When examining the same offshore cores but using samples from the upper units dated from ca. 5000 years BP to the Late Holocene, measure- 


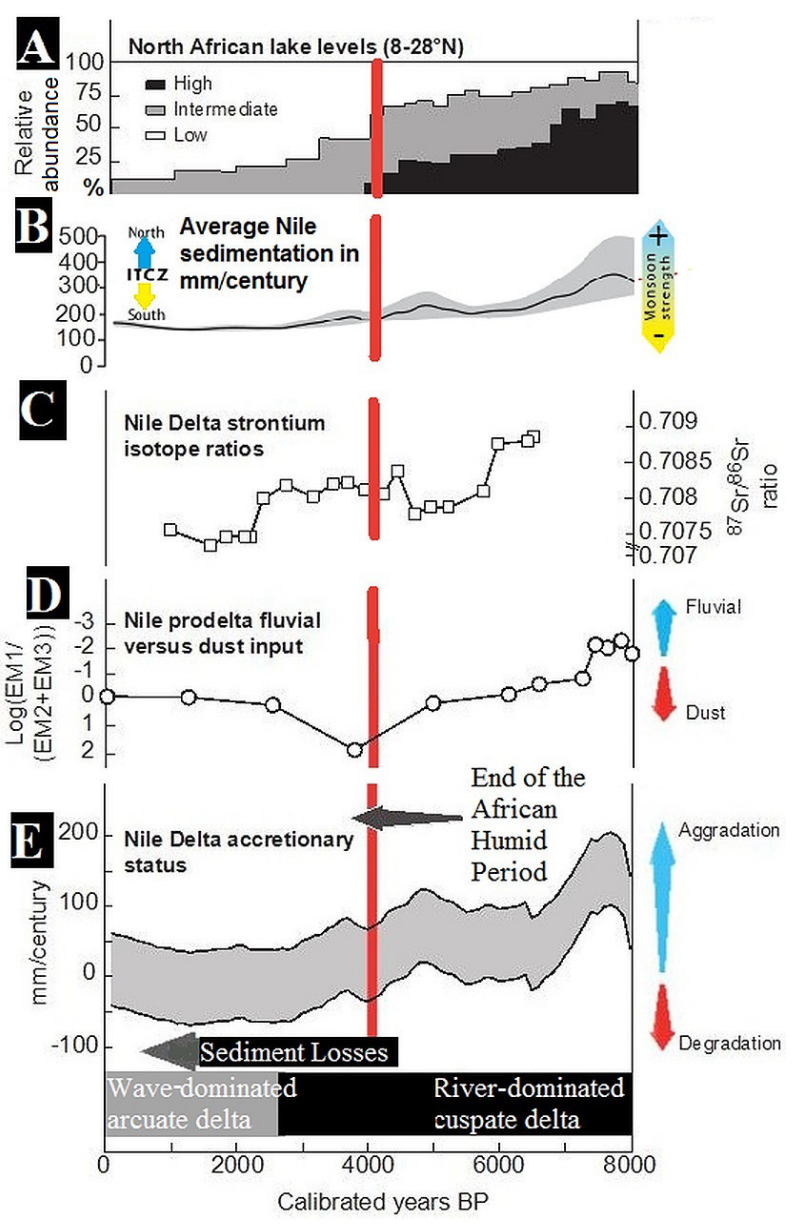

Figure 4. Sedimentation and compositional data respond to climatic change affecting (a) highland Nile source area, and (b-e) Nile Delta and offshore settings from ca. 8000 years BP to present (modified after Marriner et al., 2012, 2013). Changes in the Nilotic hydrological system and associated depositional responses during the Holocene include those before, at, and after ca. late 4000 years BP (vertical red time marker). These were induced largely by displacement of the monsoon system and associated climatic controls, including migrating ITCZ and ENSO events.

ments of their depositional rates are very much decreased (Fig. 2) and range from only 32 to $1 \mathrm{~cm}$ per 1000 years (data in Ducassou et al., 2009). The overall averaged value for all 23 upper core sections provides a much reduced average depositional rate of only $\sim 8.4 \mathrm{~cm}$ per 1000 years, or under $\sim 10 \%$ of the average accumulation rate of underlying Early to Middle Holocene S1 sequences. This records that the former turbidite-rich downslope depositional system had decreased substantially largely as a function of the Nile's much-altered hydrology and reduced sediment dispersal seaward of the delta, responses largely due to markedly changing climatic conditions that were seriously affecting this region in the Late Holocene. It is also possible that a center of sedimentation was shifting toward the east.

\subsection{Effects of increased aridity and lower Nile flows}

Of note are a number of altered compositional and textural attributes recorded offshore in upper core sections (Fig. 3) that correlate with some of similar age identified in the Nile Delta (Fig. 4 and Stanley, 2019). Together these serve as proxies to help interpret regional environmental changes occurring after 5000 years BP and especially in late 4000 years BP. The much thinner accumulation of Late Holocene and younger oxidized mud and carbonate ooze (log in Fig. 3) was deposited under conditions of relatively low Nile input responding to the considerably modified climate (Kholeif and Mudie, 2009). Conditions had become increasingly arid, and sediment discharge by the Nile was much reduced during formation of the upper marl section (Calvert and Fontugne, 2001). The major increase in hyper-aridity occurred ca. 4200-4000 years BP, contemporaneously with the time when the whole of the Egyptian Sahara had become a desert as cited earlier (Pennington et al., 2019).

In contrast with underlying sapropel sequences, the uppermost sediment sections comprise markedly decreased amorphous organic matter (AOM), total organic carbon (TOC), terrestrial pollen, and spores (Fig. 3). Uppermost core units, on the other hand, are defined by their high $\mathrm{CaCO}_{3}$ content (up to $50 \%$ ) closely associated with increasingly warm climate and decreasing moisture (Kholeif and Mudie, 2009). Moreover, increased quartz grain roundness and size and especially a peak in the $\mathrm{Ca} / \mathrm{Ti}$ ratio at that time indicate an eolian influx linked to hyper-aridity (Zhao et al., 2017; Pennington et al., 2019). Upper core sections also record increased proportions of $\mathrm{Mg}$ calcite and illite (Calvert and Fontugne, 2001) and higher amounts of opaque fractions (Kholeif and Ibrahim, 2010). Such arid periods are typically characterized by a larger input of coarser particles due to reworking of older deposits (Ducassou et al., 2009) and also of kaolinite derived largely from desert source areas in North Africa (Calvert and Fontugne, 2001).

Also noted were periodic decreases in Ethiopian-derived Blue Nile clastic sediment dispersed between 6000 and 3100 years BP (Krom et al., 2002; Revel et al., 2015). This is recorded by a marked minimum in strontium isotopic ratios (Fig. 4c), an indication of decreased Blue Nile sedimentation offshore (Krom et al., 2002). Relative increases in White Nile runoff were measured at times when Blue Nile fluvial input decreased relative to that of higher eolian transport (Fig. 4d). Minimal Nile discharge occurred in the upper layer offshore during its deposition under oxic bottom water conditions and good ventilation within the water column (Fig. 4e; cf. Kholeif and Mudie, 2009; Kholeif and Ibrahim, 2010). A decrease in fluvial discharge from about 6500 to $2800 \mathrm{~m}^{3} \mathrm{~s}^{-1}$ and also in both flood frequency and intensity are estimated during the past 5000 years (Ducassou et al., 2009). These resulted in decreased sedimentation rates to less than $1 \mathrm{~mm} \mathrm{yr}^{-1}$ during some low-flood periods (Blanchet et al., 2013). Rather than primary responses to tectonic motion, eustatic sea-level rise, 
or human intervention, most lithofacies and compactional changes recorded by upper marine core sections were induced by the broad, powerful influences of regional climate shift.

\section{Archaeological implications}

Of prime consideration is whether the evolving natural events discussed in the previous sections would have had sufficient input to trigger societal changes in Egypt in late 4000 years BP, during the latter part of the Old Kingdom (ca. 2278$2181 \mathrm{BCE}$ ) and the First Intermediate Period (ca. 21812055 BCE) (dates after Shaw, 2000). Archaeologists tend to focus on the primary roles of evolving social, political, and/or economic factors during that timeframe and, to a lesser extent, on the potential effects of climate change. Their studies of this period tend to evaluate the role of environmental impacts on Egypt in one of three different ways: (1) little or no environmental changes occurred, were not influential, or had little societal effect at about this time (Moreno Garcia, 2015); (2) some environmental changes may have occurred but were not primarily responsible for triggering or activating major societal changes recorded during that period (Seidlmayer, 2000; Moeller, 2005); or (3) environmental conditions seriously impacted Egypt and were largely responsible for some extensive, and possibly traumatic, scenarios leading to social, political, and economic upheaval (the so-called "Dark Age" scenarios) then affecting the country such as those summarized by Vandier (1936), Bell (1971), and Hassan (2007).

For a recent example of archaeological support for the concepts of group (1) above, one can read the following: "Contrary to traditional interpretations of the end of the Old Kingdom, recent archaeological research shows no trace of climatic or subsistence crisis" (Moreno Garcia, 2015, p. 79). In contrast, it is noted that some historical documents previously cited by Egyptologists of group (3) to support arguments favoring major climate change and its dire effects on society at the end of the Old Kingdom are now recognized as having been documented long after the actual period that they describe. Moreover, others referring to documents used by group (3) to describe a major breakdown of the social order at that time have also indicated that considerable discretion should be used. For example, some suggest that Egyptian writings during those early years had a tendency to exaggerate the extent of damage and disorder and thus should be cautiously interpreted before using these as firm and accurate evidence of such past events (Freeman, 1996).

Archaeologists generally agree, however, that a centralized government long and firmly controlled by a sequential reign of pharaohs had all but ceased by the end of the Old Kingdom, and Egypt proceeded for a century, or perhaps somewhat longer, without such an authoritative leader as head of state. This occurred shortly after the lengthy reign of Pepy II, estimated at some time between $\sim 2284$ BCE and $\sim 2184$ BCE. Following closely, the pharaoh was replaced by a series of concurrent nomarchs, or governors, charged with organizing and directing many of the primary activities in Egypt's many nomes, or geographic districts. In addition to these major political alterations during the First Intermediate Period, it is proposed here that the country's stability would have been weakened by the powerful environmental factors triggered by major climate change at about the same time as recorded in this study. The quality of construction at this time, in some cases, may have decreased markedly (Fig. 5). In particular, a period of marked increased aridity and decline in moisture and rainfall leading to intermittent low Nile floods lasting a century or longer likely led to episodic conditions of diminished cultivation and reduced harvests. Additionally, such periods of decreased food supplies and their less-than-well-organized storage and equitable distribution to the population had the potential to last for several years at a time, some triggering serious societal consequences (Weiss and Bradley, 2001). These conditions, in turn, would probably have also given rise to some documented migration from the delta to areas in middle and upper Egypt, some of which were then perhaps less acutely impacted by the altered environmental factors in lower Egypt.

To help resolve whether the timing of environmental impacts on Egypt can be correlated with historic events at the end of the Old Kingdom and during the First Intermediate Period, it would be useful to encourage collections and detailed mineralogical and geochemical study of sediment drill cores recovered within, and also adjacent to, established archaeological sites of that time period. Collecting closely spaced core samples and dating where possible with plant fossils in delta and marine microfossils offshore using carbon-14 dating, along with other refined dating methodologies, coupled with detailed compositional analyses at the same stratigraphic levels are now necessary tasks of primary geoarchaeological importance. For example, it should be recognized that proportions of some sediment components in both offshore and deltaic samples would likely have been altered during transport, sometimes for long distances and over a considerable period of time, prior to their final deposition at a core's recovery site on land or at sea. At least some particles and isotopic components that comprise a sample would likely not have been displaced during one single short-period transport event from source to final depositional site but rather by what is termed a longer "stop-and-go" sedimentation process (Stanley, 2019). This displacement would have involved several downslope reworking phases by repeated deposition and storage-erosion and displacement-redeposition episodes over time. As a consequence, a date obtained by calibrated C-14 or other means may well record an age for sample particles that is likely to be older than the actual younger date of a sample's final deposition. Thus, some dates obtained in both Nile Delta and offshore cores can record a time that can be on the order of 50 to 100 or more years older than what is likely to be their actual younger dates of final deposition (see 


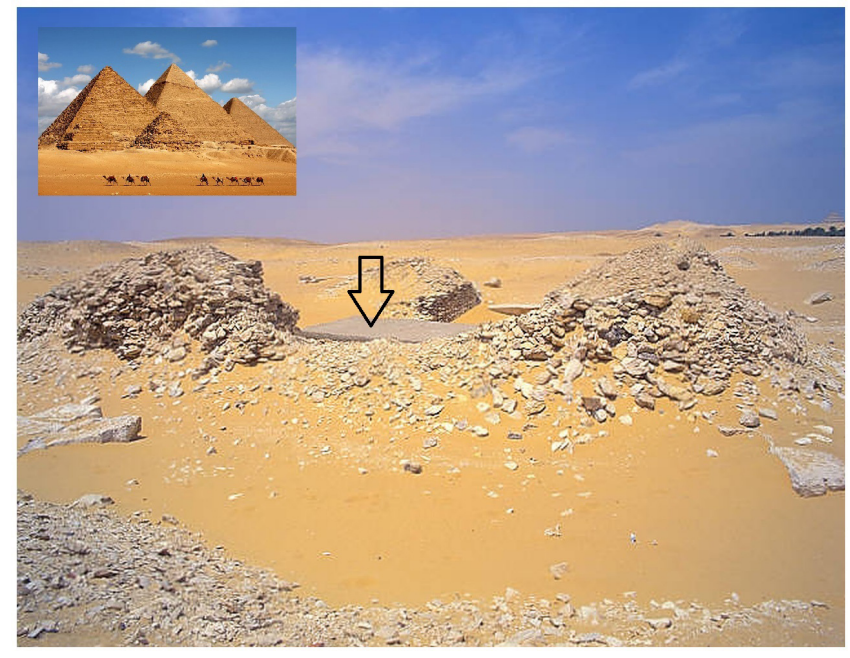

Figure 5. Pyramid of Ibi (Qakare) at South Saqqara, Egypt, built after the end of the Old Kingdom during the Eighth Dynasty of the First Intermediate Period. Ibi is little known and is believed to have ruled for about 2 years, from ca. 4109 to 4107 years BP. The structure includes a descending passage (see arrow) that leads to the burial chamber, and of its original height of ca. $21 \mathrm{~m}$, only $\sim 3 \mathrm{~m}$ now rests above the desert floor. Built largely of flat bricksize stones, it has been subject to destruction by weathering, structural failure, and theft of its rock material. In contrast, the upper inset shows the older, much larger, and better-constructed Old Kingdom Fourth Dynasty pyramids at Giza. From right to left are those of Khufu (ca. 4550 years BP), Khafre (ca. 4520 years BP), and Menkaure (ca. 4490 years BP). Khufu's pyramid, the highest (146 m), is formed of $\sim 2$ million large blocks of rock weighing 2.5 to $15 \mathrm{t}$. (Images publicly available as stock photographs.)

Dee, 2017). Caution is warranted particularly when interpreting sediment accumulation dates, especially in cases where a frequent reversal of sample ages (older dated samples above younger ones) occur as one proceeds upward from the base of a core study section.

\section{Conclusions}

The stratigraphic and sedimentological changes recorded both seaward of and in the Nile Delta proper during the Middle to Late Holocene examined herein resulted primarily from altered and reduced Nile flow conditions rather than from other natural factors and human intervention. It is proposed that marked climatic change led to intensified aridification, a decline in rainfall, diminished Nile flood levels, and a consequent periodic decline in agricultural production in late 4000 years BP. Such events would have negatively impacted Egypt's population toward the end of the Old Kingdom and in the early to middle First Intermediate Period. Of note in this respect is Herodotus (1987), who in his The History written in about $440 \mathrm{BCE}$, raised a pertinent question (Book II, Sect. 14): "If no rain falls in their land at all, and if the river cannot rise high enough to flood their fields ... then ... what will be left for Egyptians that live there, but starvation?" This commentary could pertain to an actual event that occurred prior to or during Herodotus' travel in Egypt or is perhaps meant as a predictor of future major climate changes such as increased droughts (Tabari and Willems, 2018; Nashwan et al., 2020) and of a substantial human-induced decreased-Nile-flow misfortune, such as by closure of the now near-completed Grand Ethiopian Renaissance Dam (GERD) placed across the Blue Nile in Ethiopia, the largest such structure in Africa (Stanley and Clemente, 2017). At the very least, these latter two factors alone warrant prompt and serious consideration that should lead to vital protection measures for Egypt. With its present population about 100 times greater than at the end of the Old Kingdom, the country cannot now readily withstand a $20 \%$ to $30 \%$ or more reduction in its present Blue Nile freshwater supply. Studies of this region's past history, such as those that integrate environmental and archaeological conditions in the late 4000 years BP, may provide some useful points serving as a basis to help interpret the present and also to better prepare for possible negative conditions in the years ahead.

Data availability. Information provided throughout the text is available in prior published studies by the first author (Jean-Daniel Stanley) and other authors cited throughout the text and listed in the references. These studies are readily available, and their data sets are publicly accessible therein. Data were gathered from prior original studies and are not stored in a separate database or website elsewhere.

Author contributions. This manuscript was prepared by JDS and SEW; conceptualization and project administration were completed by JDS, and visualization was completed by both SEW and JDS.

Competing interests. The authors declare that they have no conflict of interest.

Special issue statement. This article is part of the special issue "Geoarchaeology of the Nile Delta". It is a result of the workshop "Geoarchaeology of the Nile Delta: Current Research and Future Prospects”, Würzburg, Germany, 29-30 November 2019.

Acknowledgements. The Smithsonian Institution's National Museum of Natural History, Washington, DC, is acknowledged for funding years of fieldwork seaward of and in Egypt's Nile Delta and for laboratory analyses that led to this study. Appreciation is expressed to Emmanuelle Ducassou, Université de Bordeaux, France; Suzan Kholeif, National Institute of Oceanography and Fisheries, Alexandria, Egypt; and Nick Marriner, Université de Franche-Comté, Besançon, France, for permission to use several of their published figures presented herein. Also thanked are Christo- 
pher E. Bernhardt, US Geological Survey; Paige Eager, Hood College; Adrienne N. Ellis, Adamstown, Maryland; and the two anonymous scholars for their useful reviews. The editors of this volume very kindly invited our contribution and assisted us in taking final steps for its publication.

Financial support. The article processing charge was funded by the Quaternary scientific community, as represented by the host institution of EGQSJ, the German Quaternary Association (DEUQUA).

Review statement. This paper was edited by Julia Meister and reviewed by two anonymous referees.

\section{References}

Bar-Matthews, M. and Ayelon, A.: Mid-Holocene climate variations revealed by high-resolution speleothem records from Soreq Cave, Israel and their correlation with cultural changes, The Holocene, 21, 163-171, https://doi.org/10.1177/0959683610384165, 2011.

Bard, K. A.: An Introduction to the Archaeology of Ancient Egypt, Blackwell Publishing, Maulden, Massachusetts, 400 pp., ISBN13: 978-1405111485, 2008.

Bell, B.: The dark ages in ancient history, Am. J. Archaeol., 75, 1-26, https://doi.org/10.2307/503678, 1971.

Bellaiche, G., Zitter, T., Droz, L., Gaullier, V., Mart, Y., and Mascle, J.: Le cône sous-marin profound du Nil: principaux résultats de la campagne Prismed II du N.O. L'Atlante, Océanographie, 329, 727-733, https://doi.org/10.1016/S1251/8050(00)88492-X, 1999.

Bernhardt, C. E., Norton, S. P., and Stanley, J.-D.: Nile delta vegetation response to Holocene climate variability, Geology, 40, 615618, https://doi.org/10.1130/G33012.1, 2012.

Blanchet, C. L., Tjallingii, R., Frank, M., Lorenzen, J., Reitz, A., Brown, K., Feseker, T., and Brückman, W.: Highand low-latitude forcing of the Nile River regime during the Holocene inferred from laminated sediments of the Nile deep-sea fan, Earth Planet. Sc. Lett., 364, 98-110, https://doi.org/10.1016/j.epsl.2013.01.009, 2013.

Blanchet, C. L., Contoux, C., and Leduc, G.: Runoff and precipitation dynamics in the Blue and White Nile catchments during the mid-Holocene: A data-model comparison, Quaternary Sci. Rev., 130, 222-230, https://doi.org/10.1016/j.quascirev.2015.07.014, 2015.

Butzer, K. W.: Early Hydraulic Civilization in Egypt, University of Chicago Press, Chicago, Illinois, 134 pp., ISBN: 0-226-08634-8, 1976.

Butzer, K. W.: Long-term Nile flood variation and political discontinuities in Pharaonic Egypt, in: From Hunters to Farmers: The Causes and Consequences of Food Production in Africa, edited by: Clark, J. D. and Brandt, S. A., University of California Press, Berkeley, California, 102-112, ISBN: 0520045742, 1984.

Calvert, S. E. and Fontugne, M. R.: On the late PleistoceneHolocene sapropel record of climatic and oceanographic vari- ability in the eastern Mediterranean, Paleoceanography, 16, 7894, https://doi.org/10.1029/1999PA000488, 2001.

Dee, M. W.: Absolute dating climatic evidence and the decline of Old Kingdom Egypt, in: The Late Third Millenium in the Ancient Near East. Chronology, C-14, and Climate Change, edited by: Hoflmayer, F., University of Chicago, Oriental Institute Seminars no. 11, Chicago, Illinois, 323-331, 2017.

Ducassou, E., Migeon, S., Mulder, T., Murat, A., Capotondi, L., Bernasconi, S., and Mascle, J.: Evolution of the Nile deep-sea turbidite system during the Late Quaternary: influence of climate change on fan sedimentation, Sedimentology, 56, 2061-2090, https://doi.org/10.1111/j.1365-3091.2009.01070.x, 2009.

El-Sayed, A., Kerrat, I., and Hussein, H. M.: Seismicity and seismic hazard in Alexandria and its surroundings, Pure Appl. Geophys., 161, 1003-1019, https://doi.org/10.1007/s00024-0032488-8, 2004.

Fleming, K., Johnston, P., Zwartz, D., Yokoyama, Y., Lambeck, K., and Chappell, J.: Refining the eustatic sea-level curve since the last Glacial Maximum using far- and intermediate-field sites, Earth Planet. Sc. Lett., 163, 327-342, https://doi.org/10.1016/S0012-821X(98)00198-8, 1998.

Freeman, C.: Egypt, Greece and Rome: Civilizations of the Ancient Mediterranean, Oxford University Press, Oxford, England, 784 pp., ISBN: 9780199651924, 1996.

Frihy, O. E. and Dewidar, K. M.: Patterns of erosion/sedimentation, heavy mineral concentration and grain size to interpret boundaries of littoral sub-cells of the Nile Delta, Egypt, Mar. Geol., 199, 27-43, https://doi.org/10.1016/S0025-3227(03)00145-2, 2003.

Gasse, F.: Hydrological changes in the African tropics since the last glacial maximum, Quaternary Sci. Rev., 19, 189-211, https://doi.org/10.1016/S0277-3791(99)00061-X, 2000.

Hassan, F. A.: Droughts, famine, and the collapse of the Old Kingdom: Re-reading Ipuwer, in: The Archaeology and Art of Ancient Egypt, edited by: Hawass, Z. A. and Richards, J., Publications du Conseil Suprême des Antiquités de l'Egypte, Cairo, Egypt, 1, 357-379, ISBN: I0977-437-241-7, 2007.

Herodotus: The History, translated by: Grene, D., The University of Chicago Press, Chicago, Illinois, 710 pp. ISBN: $9780226327723,1987$.

Kaniewski, D., Marriner, N., Cheddadi, R., Guiot, J., and Van Campo, E.: The $4.2 \mathrm{kaBP}$ event in the Levant, Clim. Past, 14, 1529-1542, https://doi.org/10.5194/cp-14-1529-2018, 2018.

Kebeasy, R.M.: Seismicity, in: The Geology of Egypt, edited by: Said, R., A.A. Rotterdam, the Netherlands, Balkama, 51-59, ISBN: 978-9061918561, 1990.

Kholeif, S. and Ibrahim, M. I.: Palynofacies analysis of inner continental shelf and middle slope sediments offshore Egypt, southeastern Mediterranean, Geobios, 43, 333-347, https://doi.org/10.1016/j.geobios.2009.10.006, 2010.

Kholeif, S. and Mudie, P.: Palynological records of climate and oceanic conditions in the late Pleistocene and Holocene of the Nile Cone, southeastern Mediterranean, Egypt, Palynology, 33, 1-24, https://doi.org/10.2113/gspalynol.33.1.1, 2009.

Krom, M. D., Stanley, J.-D., Cliff, R. A., and Woodward J. C.: Nile River sediment fluctuations over the past 7000 years and their key role in sapropel development, Geology, 30, 71-74, https://doi.org/10.1130/00917613(2002)030<0071:NRSFOT>2.0.CO;2, 2002. 
Maldonado, A. and Stanley, J.-D.: The Nile Cone: submarine fan development by cyclic sedimentation, Mar. Geol., 20, 27-40, https://doi.org/10.1016/0025-3227(76)90073-6, 1976.

Marriner, N., Flaux, C., Kaniewski, D., Morhange, C., Leduc, G., Moron, V., Chen, Z., Gasse, F., Empereur, J.-Y., and Stanley, J.-D.: ITCZ and ENSO-like pacing of Nile delta hydrogeomorphology during the Holocene, Quaterernary Sci. Rev., 45, 73-84, https://doi.org/10.1016/j.quascirev.2012.04.022, 2012.

Marriner, N., Flaux, C., Morhange, C., and Stanley, J.-D.: Tracking Nile Delta vulnerability to Holocene change, PLoS One, 8, 1-9, https://doi.org/10.1371/journal.pone.0069195, 2013.

Moeller, N.: The First Intermediate Period: A time of famine and climate change?, Egypt and the Levant, 15, 153-167, 2005.

Moreno Garcia, J.: Climatic change or sociopolitical transformation? Reassessing late 3rd millennium BC in Egypt, in: 2200 BC - A Climatic Breakdown as a Cause for the Collapse of the Old World, edited by: Meller, H., Arz, H. W., Jung, R., and Risch, R., Landesamt für Denkmalpflege und Archäologie Sachsen-Anhalt - Landesmuseums für Vorgeschichte, Halle, 79-94, 2015.

Nashwan, N. S., Shahid, S., and Chung, E.-S.: High-resolution climate projections for a densely populated Mediterranean region, Sustainability, 12, 23 pp., https://doi.org/10.3390/su12093684, 2020.

Pennington, B. T., Sturt, F., Wilson, P., Rowland, J., and Brown, A.: The fluvial evolution of the Holocene Nile Delta, Quaternary Sci. Rev., 170, 212-231, https://doi.org/10.1016/j.quascirev.2017.06.017, 2017.

Pennington, B. T., Hamdan, M. A., Pears, B. R., and Sameh, H. I.: Aridification of the Egyptian Sahara 5000-4000 cal BP revealed from $\mathrm{X}$-ray fluorescence analysis of Nile Delta sediments at Kom al-Ahmer/Kom Wasit, Quatern. Int., 514, 108-118, https://doi.org/10.1016/j.quaint.2019.01.015, 2019.

Revel, M., Ducassou, E., Skonieczny, C., Colin, C., Bastian, L., Bosch, D., Migeon, S., and Mascle, J.: 20,000 years of Nile River dynamics and environmental changes in the Nile catchment area as inferred from Nile upper continental slope sediments, Quaternary Sci. Rev., 130, 200-221, https://doi.org/10.1016/j.quascirev.2015.10.030, 2015.

Rohling, E. J. and Hilgen, F. J.: The eastern Mediterranean climate at times of sapropel formation: a review, Geol. Mijnbouw, 70, 253-264, ISBN: 0016-7746, 1991.

Ross, D. A. and Uchupi, E.: Structure and sedimentary history of southeastern Mediterranean sea - Nile Cone area, AAPG Bull., 61, 872-902, https://doi.org/10.1306/C1EA4397-16C911D7-8645000102C1865D, 1977.

Said, R.: The River Nile: Geology, Hydrology, and Utilization, Pergamon Press, Tarrytown, New York, 320 pp., ISBN: 0-08041886-4, 1993.

Seidlmayer, S.: The First Intermediate Period, in: The Oxford History of Ancient Egypt, edited by: Shaw, I., Oxford University Press, Oxford, England, 118-147, ISBN: 978-0-19-2804587, 2000.

Sestini, G.: Implications of climatic changes for the Nile Delta, in: Climatic Change and the Mediterranean, edited by: Jeftic, L., Milliman, J. D., and Sestini, G., Edward Arnold, London, England, 535-601, ISBN: 0-340-55329-4, 1992.

Shaw, I. (Ed.): The Oxford History of Ancient Egypt, Oxford University Press, Oxford, England, 552 pp., ISBN: 978-0-19280458-7, 2000.
Sivan, D., Wdowinski, S., Lambeck, K., Galili, E., and Raban, A.: Holocene sea-level changes along the Mediterranean coast of Israel, based on archaeological observations and numerical model, Palaeogeogr Palaeocl., 167, 101-117, https://doi.org/10.1016/S0031-0182(00)00234-0, 2001.

Stanley, J.-D.: Egypt's Nile Delta in late 4000 Years BP: Altered flood levels and sedimentation, with archaeological implications, J. Coastal. Res., 35, 1036-1050, https://doi.org/10.2112/JCOASTRES-D-19-00027.1, 2019.

Stanley, J.-D. and Clemente, P. L.: Increased land subsidence and sea-level rise are submerging Egypt's Nile Delta coastal margin, GSA Today, 27, 4-11, https://doi.org/10.1130/GSATG312A.1, 2017.

Stanley, J.-D. and Maldonado, A.: Nile Cone: Late Quaternary stratigraphy and sediment dispersal, Nature, 266, 129-135, https://doi.org/10.1038/266129a0, 1977.

Stanley, J.-D. and Warne, A. G.: Nile Delta: recent geological evolution and human impact, Science, 260, 628-634, https://doi.org/10.1126/science.260.5108.628, 1993.

Stanley, J.-D., Krom, M. D., Cliff, R. A., and Woodward, J. C.: Nile flow failure at the end of the Old Kingdom, Egypt: Strontium isotopic and petrologic evidence, Geoarchaeology, 18, 395-402, https://doi.org/10.1002/gea.10065, 2003.

Summerhayes, C., Sestini, G., Misdorp, R., and Marks, N.: Nile Delta: nature and evolution of continental shelf sediment systems, Mar. Geol., 27, 43-65, https://doi.org/10.1016/00253227(78)90073-7, 1978.

Tabari, H. and Willems, P.: More prolonged droughts by the end of the century in the Middle East, Environ. Res. Lett., 13, 104005, https://doi.org/10.1088/1748-9326/aae09c, 2018.

UNESCO/UNDP and Arab Republic of Egypt: Coastal Protection Studies, Project Findings and Recommendations, UNDP/EGY/73/063, Final Report, UNESCO, Paris, FNR/SC/OSP/78/230, 483 pp., 1978.

U.S. Defense Mapping Agency Hydrographic Center: Mediterranean Sea, Washington, D.C., Chart N.O. 310, 1972.

Vandier, J.: La Famine dans l'Egypte Ancienne, Recherches d'Archéologie, de Philologie et d'Histoire, Institut Français d'Archéologie Orientale, Cairo, Egypt, tome 7, 176 pp., 1936.

Weiss, H. and Bradley, R. S.: What drives societal collapse?, Science, 291, 609-610, https://doi.org/10.1126/science.1058775, 2001.

Weiss, H., Courty, M. A., Wetterstrom, W., Guichard, F., Senior, L., Meadow, R., and Curnow, A.: The genesis and collapse of 3rd millennium north Mesopotamian civilization, Science, 261, 995-1004, https://doi.org/10.1126/science.261.5124.995, 1993.

Woodward, J., Macklin, M., Fielding, L., Millar, I., Spencer, N., Welsby, D., and Williams, M.: Shifting sediment sources in the world's longest river: A strontium isotope record for the Holocene Nile, Quaternary Sci. Rev., 130, 124-140, https://doi.org/10.1016/j.quascirev.2015.10.040, 2015.

Zhao, X., Liu, Y., Salem, A., Marks, L., Welc, F., Sun, Q., Jiang, J., Chen, J., and Chen, Z.: Migration of the intertropical convergence zone in North Africa during the Holocene: evidence from variations in quartz grain roundness in the lower Nile Valley, Egypt, Quatern. Int., 449, 22-28, https://doi.org/10.1016/j.quaint.2017.06.036, 2017. 